\title{
Teaching And Learning Outside The Box And The 'Soft-Side' Of Teaching Model
}

\author{
Leslie Leong, (Email: Leongl@ccsu.edu), Central Connecticut State University
}

\begin{abstract}
Traditional teaching methods have been tested, examined and many have been published in a variety of disciplines. However, newer paradigms of teaching have evolved due to the availability of technology that is implemented in many educational institutions. Besides adopting technology as a means to teaching effectiveness, the 'soft-side' of teaching are apparent among the more educated and more knowledgeable learners. Teachers are transforming from a 'figure-head' to a 'participant.' This study discussed the newer technology to be utilized in the classrooms and proposed a 'soft-side' teaching model for the 'new' effective teacher in the $21^{\text {st }}$ century. Teaching and learning outside the box are discussed.
\end{abstract}

\section{INTRODUCTION}

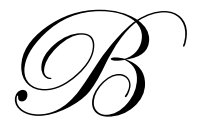

usiness organizations have changed internally from a vertical structure to a horizontal structure with the implementation of telecommunications and network infrastructure. This changed are profound in terms of sharing information across the business units and allowing the communication lines to be quicker and more effective. This is accomplished with the use of the advances in technology that is available to us. Integration of theoretical knowledge and technology has become even more important in corporate training programs.

Higher education institutions seem to be lacking behind the adoption of technology across the organization in comparison to business organizations. In education, adopting technology in teaching has become crucial. Learning technology workshops for teachers has been formed recently and more studies and discussions have emerged recently. By adopting technologies, teachers become highly effective in their job in many ways. Besides technology, teachers are transforming from a 'figure-head' (with authority and power) to a 'participant' among active learners in the classroom.

This study is three-fold. Firstly, the study proposes the newer learning methodologies, secondly by proposing the characteristics of soft-side teaching and thirdly by integrating the newer learning methodologies with the characteristics of soft-side teaching to study on learning outcomes.

As an extension to the manuscript in "Teaching E-Commerce: A Platform For Active Learning" (Leong and Petkova, 2003), this study adds two important concepts that are deemed to be effective for teaching in the knowledge era:

- $\quad$ Teaching Outside the Box

- $\quad$ 'Soft-side' of teaching.

\section{TEACHING OUTSIDE THE BOX}

Traditional classroom teaching methodologies have been widely criticized (Relan and Gillani, 1997). Other researchers concluded that despite the advances of technology, traditional model of teaching still remain the same, dysfunctional and changes must be made (Banathy, 1994; Reigeluth, 1994). Traditional methods of teaching have begun to merge with the non-traditional methods of teaching. As educators, we should embrace newer methodologies in teaching to enhance teaching effectiveness in the knowledge era. 
Some of the traditional methods of teaching consist of:

- $\quad$ Lecture where the teacher sits behind the desk or write on the whiteboards extensively;

- $\quad$ Teachers are the 'figure-head' and students are not allowed to challenge them nor speak with them unless in a respectable manner (as was found in Europe and Asia);

- Students listen, take notes, and should not deviate from the 'traditional student behavior' meaning students accept and follow what is told and taught to them by the 'figure-heads.'

These traditional teaching methods are no longer effective in today's more challenged and more educated students. It is boring, it does not motivate the students to learn more, and it is not interesting. Simply put it, it is not fun at all. These methods of teaching can be found in the 1980s and through the 1990s. However, changes have occurred in the late 1990s. Teachers began to adopt the newer methods of teaching from studies in various disciplines. This study proposes newer methodologies in teaching called 'teaching outside the box.' These are:

- $\quad$ Teaching with technology (adopting technology in and outside the classroom)

- $\quad$ Interactive learning systems (the future of and planning for interactive learning)

- $\quad$ Active learning strategies (students engaging in activities)

\section{Teaching With Technology}

Adopting technology is apparent in the knowledge economy. Higher education institutions are implementing campus-wide technology infrastructure on campus. Presentations of lecture using e-slides, e-word-processor, espreadsheets should be enhanced with web-based tools. Web based enhanced tools suitable for teaching effectiveness are vastly available. Such tools include WebCT, BlackBoard, e-college, and so on. Teachers should use these webbased teaching tools in and outside of the classrooms and reduces the use of hard copies to be handed out in class and the dissemination of information faster and more effective. Interactions among students with technology are maximized not only for on-line courses, but for on-campus courses as well. The IEEE Learning Technology Task (LTTF) Force offers newsletter, workshops, and has been founded on the premise that emerging technology has the potential to dramatically improve learning.

Web based enhanced tools provide the teachers a means to post slides, lecture notes, exams, quizzes, case studies, journal articles, announcements, discussions, chat sessions, and a quicker and effective way to grade and post grades among many other great features. Teachers are able to use all of these great features at any remote locations. Besides waiting for the next class meeting or communicating with traditional e-mail, students post questions on the discussion board(s) and the teacher responds almost immediately. All students are able to read the posted questions and responses, therefore eliminated multiple responses through e-mail. Questions(s) posted by one student are highly probable that other students may ask. Adopting and using web-based systems allows the teacher to teach effectively in the classrooms with lectures, discussions, and active learning strategies.

From the students perspective, the web based enhanced tool allows them to view lecture slides, read lecture notes, announcements, post their exams, quizzes, post discussion questions and answers. Most interestingly, students are able to get together on-line for group meetings in chat rooms or form a discussion group to complete their group project in 'real-time' without having excuses of missed meetings. Students have found this to be highly effective in group-work, peer interactions and team-learning experiences. They are able to get together anywhere, anytime, and to post their project on-line. Teachers are able to check on student's participation in-group project(s) effectively outside the classroom.

\section{Interactive Learning Systems}

Other forms of interactive learning may come from designing a system or a web site with interactive capabilities. These we have seen in Computer Based Testing (CBT) systems and other Web-based Education (WBES) Systems. However, the downside of adopting interactive learning systems requires computer-programming skills. 
These interactive learning systems are not widely available as of now unless it is customized. However, it is believed that these systems will be available from multiple vendors in the future.

As of now, on-line institutions and corporate universities have customized and adopted such systems. We will start to see the emergence of interactive learning systems where the students are able to learn with a 'teaching assistant' on-screen for reviews, practice test, and so on. The students are able to test their knowledge by challenging practice tests and getting the correct answers immediately and what the wrong choices meant by a click on the mouse. The students will be able to learn interactively which stimulates their interest in learning with fun. These are coupled by 3-D effects and voice simulations. (Subject matter expertise (SME), knowledge engineers, and knowledge workers work together to produce an interactive learning system).

\section{Active Learning Strategies}

Teaching and learning includes active learning strategies. Leong and Petkova (2003) highlighted the active learning strategies that can be implemented in the classroom. Active learning strategies includes the following:

- $\quad$ Exercise for individual students - helps student in mastering the essential material and providing the feedback concerning the student understanding and retention of material

- $\quad$ The 'one minute paper' - students are given a minute or two to respond to a specific question. This is highly effective to check on student's progress, both in understanding the material and in reacting to course materials

- $\quad$ Muddiest (or Clearest) point - a variation of the 'one minute paper', a question can be asked well before the end of class or a break session to ensure what the students have learned during the class session

- $\quad$ Extensive communication - posting answers and questions are done immediately throughout the semester by e-mail or on a web site with discussion board capabilities

- Informal small groups - specifically aimed at the support of group interaction and to improve learning, to cooperate in a common task, to give and receive constructive feedback, to respect differences of opinions and to support their judgments with evidence and to be good listeners

- Jigsaw group project - each member in the group is asked to complete some discrete part of an assignment; when completed, the pieces are joined together to form a finished product

- $\quad$ Panel discussions and debates - combining other cooperative learning technique such as role playing, panel discussions and debates are used in student's class presentations or reports as way of including the entire class

- $\quad$ Case studies - students participate to minimize or solve problems with cases for the purpose of enhancing student-teacher interaction, collaboration, problem solving, reflection, and extensive discussion. Potential for involving students in discussions that call for a higher-order level of reasoning, such as analyzing situations, forming judgments, and evaluating solutions

- $\quad$ Simulation projects - A hands-on experience for conducting proto-types of a situation by integrate theoretical insights to practical solutions

Active learning strategies with the combination of project based learning, therefore engage the students in activities in the learning environment. Project-based learning is suggested as a means for increasing skills, as well as applying conceptual material, thereby forcing students to verify their understanding (Dougherty, 2002). These roleplaying experiences help build confidence, skills, knowledge and creativity through problem-based learning. Extensive teacher-student interaction and peer-to-peer interaction becomes apparent in the learning activities. When implemented correctly, active learning strategies become fun, interesting and ultimate promote deep learning. Traditional teaching methods are therefore improved by incorporating any of the strategies mentioned above. Most importantly, active learning strategies place less emphasis on the transfer of information and greater emphasis on developing analytical and critical thinking skills.

Active learning strategies (Leong and Petkova, 2003) or group learning activities (Benbunan-Fich, 2002) are one of the most common implementations of the constructivist approach in successful learning outcomes. In these activities, knowledge is constructed by formulating ideas into words, and building upon these ideas through 
discussion, reactions, and responses of others (Alavi, M., 1994, Leidner, D. and Jarvenpaa, S., 1995). It is, therefore, important that instructors include active learning strategies in their curriculum design of MIS courses.

\section{LEARNING OUTSIDE THE BOX}

Students' should be transformed to learn outside the box, not merely to pass a class, and to achieve a grade. Learning Outside the Box is achieved when deep learning occurs, understands the learning goals, the students' care about the learning outcome that is reflective throughout their career and lifetime goals and intensify the curiosity and interest for further learning. These learning outside the box goals should be transmitted to the students' early during the course of study. They should be given the opportunity to excel in numerous ways, to reflect on the subject matter, and to reinforce confidence. Competition among students should be removed and so is studying for a grade as a reward, which is a short-term extrinsic goal.

Intellectual developments and personal developments are reinforced throughout the course. Intellectual development refers to the acquisition of the subject matter in a broader sense (from its history to its current stage) and applies them to multiple settings when anticipated. Deep learning and understand of the subject matter is reinforce by allowing them to think through active learning strategies and examinations.

Personal development refers to the ability to value and understand the activities in class that helps build confidence, social interactions among different groups, issues of ethical, political, legal, social dimensions that encompasses the involvement of action and reaction, and the emotional person as a whole when confronted with problems beyond that of intellectual growth.

Learning outside the box can be very challenging. Teachers' must be able to find out what is it that the students' care about in their life and in their course of study and transform those intrinsic motivators to reflect on the course. Extrinsic motivators should be kept to a minimum or as an expectation (letter grade, points, etc). The point here is to understand, to think and to reflect on the learning process and to foster deep learning. Memorization of facts and learning to pass an exam should not be encouraged.

\section{'SOFT-SIDE' TEACHING}

'Soft-side' teaching is an art. The characteristics change from one individual to another in terms of personality, how we see ourselves as a person and our past experiences. Some people are born to be natural leaders, politicians, motivational speakers, musician and the list goes on (and of course teachers). However, to be an effective teacher in today's challenged environment, the 'soft-side' of teaching must be learned, if not born naturally.

Teaching in the classroom has changed dramatically from the Transmission Model to the Engagement Model. In the classroom, lectures should be conducted, but with the use of a variety of format in presentations. The teacher acts as a facilitator of knowledge and resources in the teaching environment. The teacher 'manages' the class with participatory activities. Teachers should not be sitting behind the desk, nor standing behind the podium. Rather, the teacher must move freely in the classroom, looking at the students with eye contact, asking questions, asking for additional experiences and inputs the students might have in the topic being lectured upon.

Teachers must 'get to know' their students through one-to-one conversation before and after the class session, or by asking them to fill out an informational sheet. These includes asking them on why are they taking the course, what are their interests in the course and the program, how are they going to plan on learning, where are they now in their career goals, what do they seek out of from the course or program, what do they care most about the course, and finally, what are their learning objectives throughout the learning program.

As stated in Soloway (1996), "children need adult models; they need adults to care about them and to see the value in their ideas" (pp. 11). These activities encourages an open learning environment, a thinking process, and to build confidence in participating in class activities. If the teachers care about the student success and learning 
outcomes, most likely the students will care about what their learning goals are in the course, rather than to achieve a grade.

Teachers act as an advisor in projects and discussions. Teachers act as leaders in the group of learners and orchestrate the activities of active learning. Students are encouraged to freely participate in topics discussion, share their knowledge with other learners and ultimately free them from the uneasiness and unfriendly atmosphere in the traditional classroom. The perceived notion that teachers are 'figure-head' is eliminated and ultimately removes the barriers of communication. Teachers and students become learners in the environment where they share and exchange knowledge as participants in the learning environment.

Teachers have a great impact on the lives of those learners' around them in and outside of the classroom which the learners' carry with them throughout their lifetime. This is where the students learned to apply the learning outcomes to problems, situations, and cases throughout their lifetime. As a result, the 'soft-side' of teaching characteristics plays an important role on how the students perceived the teacher and the learning outcomes.

\section{The Proposed 'Soft-Side’ Teaching Model}

According to Lortie (1975), the 'soft-side' of teaching refers to empathy and patience. From Lortie's proposal, this study proposes a new model (Figure 1) that 'soft-side' teaching includes empathy, patience, passion, approachable, embrace and accept changes and personable. The constructs therefore resulted in successful learning outcomes by both the teacher and students. However, this outcome may or may not be influence by the mediators such as attitude and intent. Therefore, this model can be tested in a number of different studies. Appendix 1 provides a list of definition on the constructs.

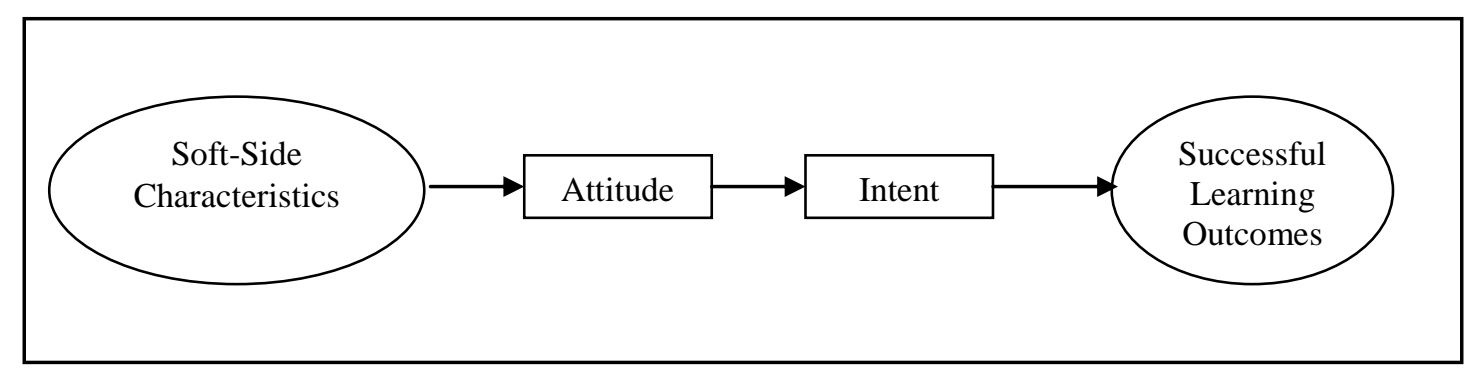

Figure 1. Proposed 'Soft-Side’ Teaching Model, Leong 2004

\section{An Integrate Model}

As an extension to the 'Soft-Side' teaching model, this model (Figure 2) integrates the concepts of teaching outside the box into the 'Soft-Side' teaching model. This integrated model can be tested in various scenarios by removing one or more of the construct(s) or adding external variable(s). Depending on the class size, some of the characteristics of soft-side teaching may not be possible to implement. This holds true for the newer teaching methodologies as well.

\section{METHODOLOGY}

\section{The Model for this Study}

Due to the robustness of the integrated model in Figure 2, this study focused on the Soft-Side characteristics variable and the Technology variable to determine successful learning outcomes (Figure 3). In this knowledge economy, it is viable to see if the use of technology has any impact on learning outcomes. (1) As a result, technology 
was chosen as an independent variable to test the dependent variable. (learning outcomes). (2) Secondly, the Soft-Side characteristics variable was used as an independent variable to test the dependent variable, the focus of the proposed model. (3) Thirdly, this study also tests if the combination of Soft-Side characteristics and technology when used jointly by a teacher would result in successful learning outcomes.

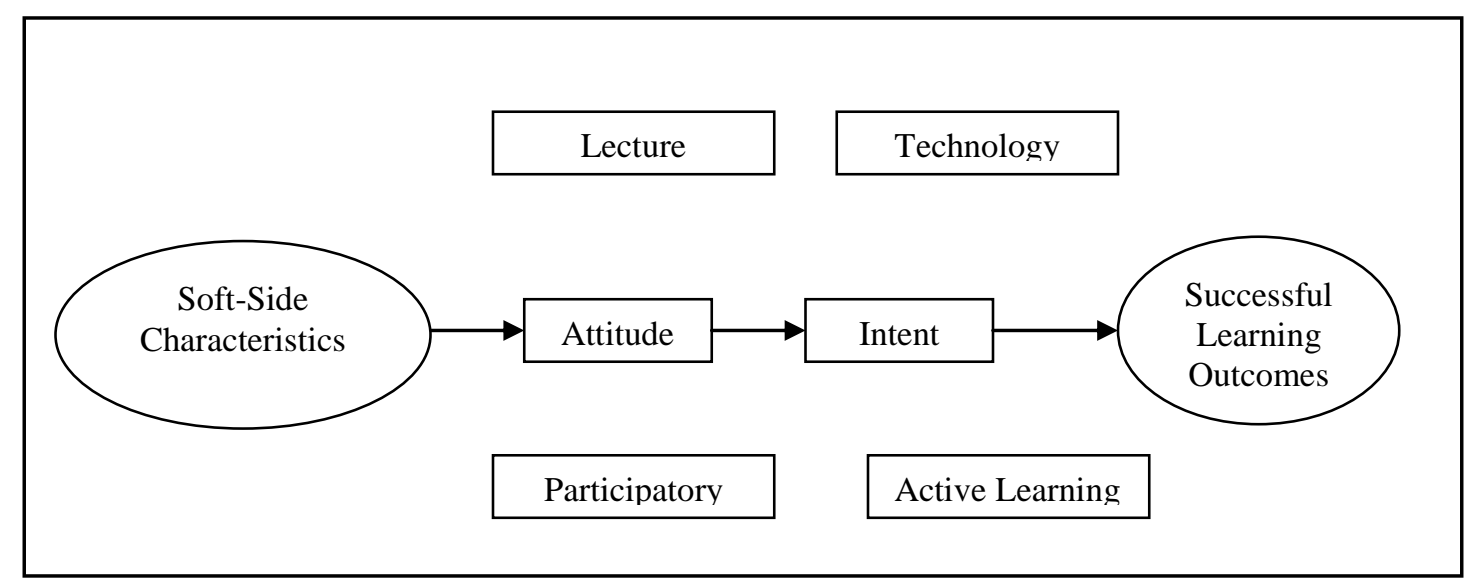

Figure 2. An Integrated Model Of The 'Soft-Side' Teaching Model, Leong 2004

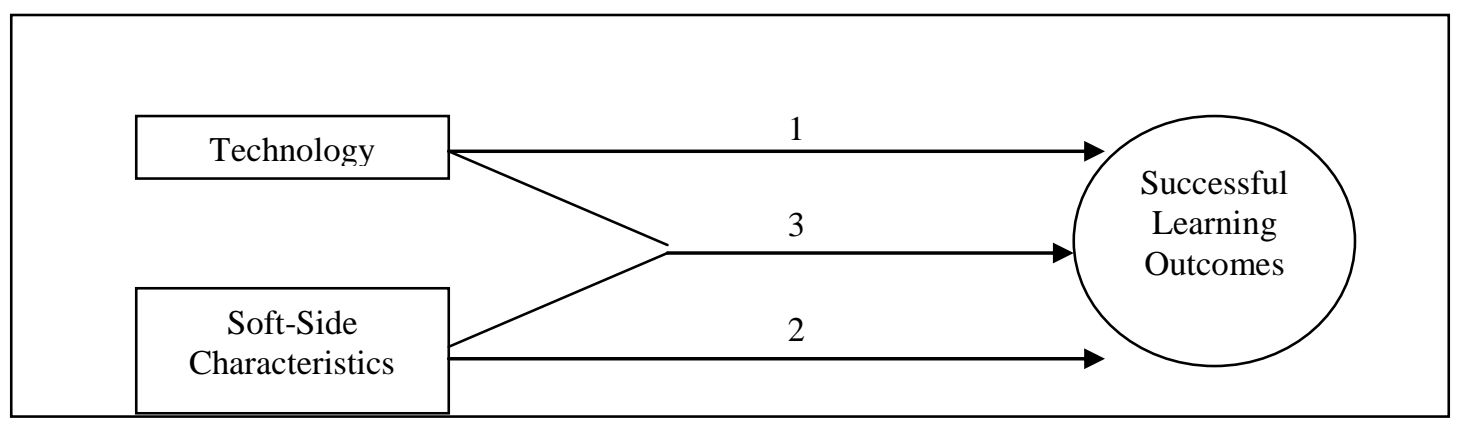

Figure 3. The Current Model Of Study

\section{Research Questions}

- Do you believe that if a teacher uses technology in the classroom, it helps the students to learn successfully?

- Do you believe that if a teacher engages in Soft-Side characteristics, it helps the students to learn successfully?

- $\quad$ Do you believe that if a teacher engages in both technology and Soft-Side characteristics, it helps the students to learn successfully?

\section{The Development Of The Survey}

The author designed and developed a questionnaire to collect information from these two groups: students and teachers. These two groups were asked questions that would result in successful learning outcomes from the two independent variables as discussed above (see Table 1 and Table 2). These two groups were selected on the rational that a) if a teacher uses technology and engages in soft-side characteristics in the classroom, students learning 
outcome can be achieved (from the teacher's perspective), and b) if a teacher uses technology and engages in soft-side characteristics, the student feels that successful learning can be achieved (from the student's perspective). The author believes that by testing these two groups, the result would be further enhanced to determine if successful learning outcomes would assist the teacher in reflecting on their perspectives and on students' perception on what constitute successful learning outcome from the two independent variables. Both groups were given the definitions of terms for reference purposes (Appendix 1).

\section{Data Collection}

The study was conducted at two universities in the Northeast of the United States. The survey was given to business school's professors (at all ranks) and college students (at all levels of undergraduate educational experiences). Due to the limited time on completing and collecting the survey in a timely fashion, a web-based survey was developed and respondents were asked to submit the survey anonymously through the web and the data were collected in a database for tabulation and analysis. E-mail was sent to 130 students and 66 professors and they were directed to a web page to complete the survey. Of the 130 students, 89 responded and completed the survey, with a response rate of $68 \%$. Of the 66 professors, 43 responded and completed the survey, with a response rate of $65 \%$.

\section{Results}

From the research questions, the following results were observed.

Q: $\quad$ Do you believe that if a teacher uses technology in the classroom, it helps the students to learn successfully?

A: $\quad 81.3 \%$ of teachers and $96.6 \%$ of students believed that technology would help student sot learn successfully.

Q: Do you believe that if a teacher engages in Soft-Side characteristics, it helps the students to learn successfully?

A: $\quad 69.7 \%$ of teachers and $100 \%$ of students believed that teachers who engage in Soft-Side characteristics would help students to learn successfully.

Q: $\quad$ Do you believe that if a teacher engages in both technology and Soft-Side characteristics, it helps the students to learn successfully?

A: $\quad 88 \%$ of teachers and $97.7 \%$ of students believed that when the teacher in and outside of the classroom engaged both technology and Soft-Side characteristics, it helps the students to learn successfully.

There are some alarming results from the data collected from the teachers in Table 1. In Q.2., 83.7\% of the teachers responded that they are familiar with using technology in and outside of the classroom, but only $79 \%$ of them use technology (Q.1). This could possibly suggest that the teachers that do not use technology simply were not trained to use it or they were reluctant to use it because they do not believe that using technology would improve learning outcomes (Q.4). Of the 79\% that uses technology, 44\% responded that they were unsure if technology helps in successful learning outcomes (Q.3). This could possibly mean that these teachers did not measure/evaluate successful learning outcomes when technology is used in and outside of the classroom.

Of the 43 teachers responded to the survey, $72 \%$ reported that they do engage in Soft-Side characteristics in teaching (Q.5). However, 71.8\% of these teachers reported that they were unsure if successful learning outcomes occurred (Q.6). This either suggests that there were no instruments used to measure the outcome of Soft-Side characteristics, or there were not found in the teaching evaluation. From the teachers' perception, $20.9 \%$ reported that they do not believe that Soft-Side characteristics would improve successful learning outcome, and $9.4 \%$ were unsure if it does (Q.7). These results could possibly come from teachers who were previously exposed to teacher-centered learning institutions or research intensive institutions where teachers are highly engage in other activities and have teaching assistants teach most of their classes.

From questions 10 to 13, it can be concluded that the majority of the teachers believe that both technology and Soft-Side characteristics are important teaching components that may lead to successful learning outcomes (88\%). 
It is to the author believes that when technology is developed, implemented and available to be used by teachers in their institutions, the usage and acceptance rate would be significantly higher than $72 \%$ (Q.11). Couple with an instrument to measure successful learning outcomes with technology, the results may be rectified.

Table 1. Teacher's Responses To Successful Learning Outcomes

\begin{tabular}{|l|c|c|c|}
\hline Questions & Yes & No & Unsure \\
\hline 1. Do you use technology in the classroom? & $79 \%$ & $21 \%$ & \\
\hline $\begin{array}{l}\text { 2. How familiar are you with using technology as a } \\
\text { means of teaching in and outside of the classroom? }\end{array}$ & $\begin{array}{c}83.7 \% \\
\text { (Familiar) }\end{array}$ & $\begin{array}{c}16.3 \% \\
\text { (Not Familiar) }\end{array}$ & \\
\hline $\begin{array}{l}\text { 3. If you use technology in the classroom, did you see } \\
\text { an improvement in successfully learning outcomes? }\end{array}$ & $45 \%$ & $11 \%$ & $74 \%$ \\
\hline $\begin{array}{l}\text { 4. Do you believe that if a teacher uses technology in } \\
\text { the classroom, it helps the students to learn } \\
\text { successfully? }\end{array}$ & $81.3 \%$ & $11.6 \%$ & $7.1 \%$ \\
\hline $\begin{array}{l}\text { 5. Do you engage in Soft-Side teaching characteristics } \\
\text { in and outside of the classroom? }\end{array}$ & $72 \%$ & $28 \%$ & \\
\hline $\begin{array}{l}\text { 6. If you do engage in Soft-Side characteristics, did you } \\
\text { see an improvement in successful learning outcome? }\end{array}$ & $23.2 \%$ & $5 \%$ & $71.8 \%$ \\
\hline $\begin{array}{l}\text { 7. Do you believe that if a teacher engages in Soft-Side } \\
\text { characteristics, it helps the students to learn } \\
\text { successfully? }\end{array}$ & $69.7 \%$ & $20.9 \%$ & \\
\hline $\begin{array}{l}\text { 8. Do you engage in both technology and Soft-Side } \\
\text { characteristics in and outside of the classroom? }\end{array}$ & $83.7 \%$ & $16.3 \%$ & \\
\hline $\begin{array}{l}\text { 9. If you do, did you see an improvement in successful } \\
\text { learning outcomes? }\end{array}$ & $41.8 \%$ & 11.7 & $5.1 \%$ \\
\hline $\begin{array}{l}\text { 10. Do you believe that if a teacher engages in both } \\
\text { technology and Soft-Side characteristics, it helps the } \\
\text { students to learn successfully? }\end{array}$ & $88 \%$ & $6.9 \%$ & \\
\hline $\begin{array}{l}\text { 11. Overall, do you believe that the quality of } \\
\text { education would be enhanced if the teacher uses } \\
\text { technology in and outside of the classroom? }\end{array}$ & $72 \%$ & $28 \%$ & \\
\hline $\begin{array}{l}\text { 12 Do you agree with this statement? “Teaching with } \\
\text { technology in and outside of the classroom is expected } \\
\text { in the current knowledge economy?" }\end{array}$ & $81.3 \%$ & $18.7 \%$ & \\
\hline $\begin{array}{l}\text { 13. Do you agree with this statement? "Engaging in } \\
\text { Soft-Side teaching characteristics is expected in the } \\
\text { current knowledge economy?" }\end{array}$ & $74.5 \%$ & $25.5 \%$ & \\
\hline
\end{tabular}

Table 2 shows the students' perspectives on successful learning outcomes. We see a dramatic shift of results as compared to the teacher's perspectives. Students are more convincing to the use of technology and are technology savvy in business schools (Q.1, 2, 3, 7, 9). Perhaps, the factor that causes the results was from a pool of students between the ages of 18 to 40 . From table 2., we see that students are more incline to believe that usage and acceptance of technology would enhance their learning outcomes. They are also susceptible to teachers who exemplify Soft-Side characteristics in and outside of the classroom (Q. 4, 5, 6, 10).

Furthermore, the author believes that students in high schools in the United States are beginning to use technology in their course work. They are exposed to the use of technology in the early ages of their education with interactive learning systems and web based learning systems. However, teachers may be more inclined to teaching methods without the use of technology or have been accustomed to teaching methods when technology was not available. This study, therefore suggest a paradigm shifts in teaching methodology in the knowledge economy. 
Table 2. Student's Responses To Successful Learning Outcomes

\begin{tabular}{|l|c|c|c|}
\hline Questions & Yes & No & Unsure \\
\hline $\begin{array}{l}\text { 1. Do you believe that if a teacher uses technology in } \\
\text { the classroom, it helps you to learn successfully? }\end{array}$ & $96.6 \%$ & & \\
\hline $\begin{array}{l}\text { 2. How familiar are you with using technology as a } \\
\text { means of learning? }\end{array}$ & $\begin{array}{c}98.8 \% \\
\text { (Familiar) }\end{array}$ & $\begin{array}{c}1.2 \% \\
\text { (Not Familiar) }\end{array}$ & \\
\hline $\begin{array}{l}\text { 3. Do you believe that teachers should be using } \\
\text { technology in and outside of the classroom to help you } \\
\text { learn successfully? }\end{array}$ & $100 \%$ & & \\
\hline $\begin{array}{l}\text { 4. Do you believe that teachers should be engaging in } \\
\text { Soft-Side characteristics in and outside of the } \\
\text { classroom? }\end{array}$ & $100 \%$ & & \\
\hline $\begin{array}{l}\text { 5 Do you believe that if a teacher engages in the Soft- } \\
\text { Side characteristics in and outside of the classroom, it } \\
\text { helps you to learn successfully? }\end{array}$ & $100 \%$ & & \\
\hline $\begin{array}{l}\text { 6. Do you believe that teachers should engage in both } \\
\text { technology and Soft-Side characteristics in and outside } \\
\text { of the classroom? }\end{array}$ & $96.6 \%$ & $3.4 \%$ & $2.3 \%$ \\
\hline $\begin{array}{l}\text { 7. Do you believe that if a teacher engages in both } \\
\text { technology and the Soft-Side characteristics in and } \\
\text { outside of the classroom, it helps you to learn } \\
\text { successfully? }\end{array}$ & $97.7 \%$ & & \\
\hline $\begin{array}{l}\text { 8. Overall, do you believe that the quality of education } \\
\text { would be enhanced if the teacher uses technology in } \\
\text { and outside of the classroom? }\end{array}$ & $97.7 \%$ & & \\
\hline $\begin{array}{l}\text { 9. Do you agree with this statement? "Teaching with } \\
\text { technology in and outside of the classroom is expected } \\
\text { in the current knowledge economy?" }\end{array}$ & $100 \%$ & & \\
\hline $\begin{array}{l}\text { 10. Do you agree with this statement? "Engaging in } \\
\text { Soft-Side teaching characteristics is expected in the } \\
\text { current knowledge economy?" }\end{array}$ & $100 \%$ & & \\
\hline
\end{tabular}

\section{DISCUSSION}

In this study, the model was modified to include technology and Soft-Side characteristics as independent variables to test on the dependent variable (successful learning outcomes). The results showed that students are far savvier in technology as a learning tool than teachers would. Students believe that teachers should be using technology in and outside of the classroom to help them to learn successfully. The study also concluded that teachers should engage in Soft-Side characteristics in and outside of the classroom. Students believe that it would help them to learn successfully, however approximately half of the teachers reported that they don't see an improvements or they were unsure of the learning outcomes. It is the author's argument that these results were compelling that there may not be an instrument in measuring the learning outcomes when these variables were used. Assessment or rubrics tools will need to be developed to assess from these learning outcomes.

In Table 1, Q. 1 and Q 5. show that 21\% of the teachers do not use technology in the classroom. 28\% do not engage in Soft-Side characteristics. In comparison, in Table 2, Q 1 and Q.6 show that students (96.6\%) believe that teachers who use technology and soft-side characteristics help them to learn successfully.

The current study confirmed that teaching with both technology and engaging in Soft-Side characteristics are expected in the current knowledge economy. The data collected also confirmed that both groups believe that these 
variables, when used together effectively, improve successful learning outcomes. $97.7 \%$ of the students believed that when both technology and Soft-Side characteristics were used in and outside of the classroom, they help the students to learn successfully. These results confirms that teachers should be changing their teaching methods and teaching styles to suit the needs of the students.

This study proposes that 'Teaching Outside the Box' is an emerging trend for teaching effectiveness in the knowledge era. Traditional methods of teaching must be accompanied by the newer methodologies such as teaching with technology, planning for interactive learning systems and active learning. There is no one discipline that should avoid including technology in their curriculum and teaching methods (as was shown by the result of this study). It is expected in today's highly challenged economy and highly advanced knowledge workers that teachers of higher educational institutions must act to become the forefront by adopting technology. Industries have used technology in their training programs to facilitate the transition of theory to practice.

Furthermore, this study proposes the characteristics of 'Soft Side Teaching.' Subject matter expertise is not in question here, but rather, how effective you are as a teacher in encompassing the characteristics of soft-side teaching (empathy, patience, passion, approachability, changes, and personable). Unlike a science of teaching methodologies, 'soft side teaching' characteristics is an art because it can be difficult to learn and to acquire. It includes the psychological, sociological, and behavioral understanding of how human beings learn, the intrinsic and extrinsic motivators, and do they care about learning. However, it is to the author's believe that most teachers do have these characteristics and can be learned but research studies have not yet been conducted on the effectiveness of these characteristics that a teacher possess and used inside and outside of the classroom.

With the characteristics of 'soft side teaching,' the author proposes a new model to measure successful learning outcomes (Figure 1). This model shows that teaching with the 'soft side' characteristics by the teacher results in a greater possibility of successful learning by the students. Two other factors must also be considered: attitude and intent. Attitude refers to the teacher's attitude of adopting technology and new teaching concepts. Intent refers to the extent that the teachers will use the technology and newer teaching concepts. These factors may influence the learning outcomes therefore become the mediators of the model.

As an extension to the 'Soft Side Teaching' model, the author added external variables such as lecture, participatory, technology, and active learning strategies to the model (which are the 'hard-side' of teaching that can be easily learned, followed, and acquired) as shown in Figure 2. These external variables enhance the model in a variety of reasons.

Firstly, 'soft side teaching' characteristics are integrated with the traditional transmission model of teaching methods such as lectures and discussions. It is appropriate to think that teaching must include some sort of teaching methods to transfer knowledge of the course being taught. Secondly, participatory teaching methods can be integrated in the model. Participatory teaching method includes seminars, panel discussions, debates sessions and so on where both the teacher and students contribute and share their knowledge in the topics being discussed and presentations made by the students. Thirdly, technology is adopted in the classroom with the 'soft side teaching' characteristics to enhance successful learning outcomes. In this study, the use of technology is an important factor to be included in the 'Soft Side Teaching' model.

Lastly, the use of active learning strategies adopted in the classroom will greatly affect successful learning outcomes. Active learning strategies include a variety of activities that the students are engage in throughout the semester inside and outside of the classroom.

\section{CONCLUSIONS AND FUTURE RESEARCH}

This study proposed the concepts of "Teaching Outside the Box" and the model of "Soft- Side Teaching." The current study in Figure 3 confirmed that both of these concepts are believe to enhance successful learning outcomes from both the teachers and students. Future research can be conducted by testing the integrated model in a 
number of different settings. The author of this study suggests applying the model in a variety of scenarios such as class size, course level, and discipline among others.

It is, however, difficult to access these methods of teaching in large classes. The traditional transmission model may seem more appropriate. It is also interesting to see if the model holds true in different countries since cultures and customs play an important role in teaching. In some cultures, teachers are perceived to be of a high social rank citizen, and exemplify respectable manners and behaviors in and outside the classroom. 'Soft side teaching' characteristics may be not appropriate in that culture. It would be interesting to see the result of that study.

In the information systems and information technology field of study, incorporating technology into the classroom cannot be avoided. The types of technology to be adopted can be studied upon in a number of settings as well. However, the question arises with using technology and being patient. What is the relationship between those two? One may ask. In this context, both the teacher and the students must have patient with technology. Both teachers and students may encounter problems when they are unable to access the materials from the network or the PC is dysfunctional during the class period. As a result, they should have an alternative plan on how they could get the materials across while waiting for the systems to work again.

The development of the 'Soft Side Teaching' model(s) and the methods for effective teaching in 'Teaching Outside The Box' presents enormous challenges and opportunities to both academics and industries. Future study may concentrate on the development of the model with instruments to test the effectiveness of the model by applying variables to test learning outcomes. This study has discussed on 'Teaching Outside The Box' with technology, planning for interactive learning systems and incorporating active learning strategies as well as the characteristics of the 'Soft Side Teaching' model.

\section{REFERENCES}

(1) Alavi, M. (June, 1994). Computer-mediated collaborative learning: An empirical evaluation. MIS Quarterly, 150-174.

(2) Benbunan-Fich, R. (June 2002). Improving Education and Training with IT. Communications of the ACM, 45 (6), 94-99.

(3) Banathy, B. (1994). Designing Educational Systems: Creating our future in a changing world. In C.M. Reigeluth \& R.J. Garfinkle (Eds), Systemic change in education (pp. 27-34). Englewood Cliffs, NJ: Educational Technology Publications.

(4) Dougherty, J.P. (2002). Information technology fluency at a liberal arts college: experience with implementation and assessment. In Proceeding of the CCSC: Eastern Conference, Consortium for Computing Sciences in Colleges, 166-172.

(5) Leidner, D. and Jarvenpaa, S. (Sept.1995). The use of information technology to enhance management school education: A theoretical view. MIS Quarterly, 265-291.

(6) Leong, Leslie and Petkova, Olga (2003). Teaching E-Commerce: A Platform for Active Learning, International Business and Economics Research Journal, 2 (3), 17-21.

(7) Lortie, D. (1975). Schoolteacher: A sociological study. Chicago: University of Chicago Press.

(8) Reigeluth, C.M. (1994). Introduction: An imperative for system change, In C.M. Reigeluth \& R.J. Garfinkle (Eds), Systemic change in education. Englewood Cliffs, NJ: Educational Technology Publications.

(9) Relan, A., and Gillani, B. (1997). Web-based information and the traditional classroom. In B. Khan (Ed.), Web based instruction (pp. 135-138). Englewood Cliffs, NJ: Educational Technology Publications.

(10) Soloway, Elliot. (1996). Teachers are the key. Communications of the ACM. 39 (6), 11-14. 


\section{APPENDIX 1}

\section{Definition of terms:}

Empathy

Teachers understands and put themselves in the 'shoes' of the students in the learning environment

Patience

Teachers treat all students fairly in acquiring and implementing knowledge, also with those students that are 'slow-learners', and with disabilities

Passion

Approachable

Teachers who show an interest in their discipline by
who cares and are concern about students' success

Teachers are open toward criticism and praise, and are always available for their students for any course related questions in a friendly manner. Anytime, anywhere in and out of classroom

Changes

Teachers are willing to embrace and accept technology into their curriculum and teaching methodologies

Personable

Lecture

Technology

Participant

Teachers are friendly, cares about the student success and respect students comments

Lecturing with participatory teaching in the classroom

Using technology in and outside the classroom (web-based systems, interactive learning systems, etc)

Active Learning

Teachers are both a learner and an expert in the subject

Attitude

Students are engaged in activities in and outside the classroom

Teachers attitude towards embracing new technology and new teaching concepts

Intent

Teachers intent to use technology and new teaching concepts

Learning Outcomes

The result of student's learning and assessment 